\title{
Sedimentation of Turkish Knowledge about the Genocide-and Comparisons
}

Research on Turkish knowledge about the Armenian genocide identifies deeply ingrained and systematic denial by the Turkish state and most of its citizens. As in the case of Armenians' genocide knowledge, however, scholars find that groupspecific memories are not a constant. They solidify over time, as Stanley Cohen observes of the years after World War I: "This is not the usual story of initial unconfirmed rumours giving way to certain truths.... Rather, the opposite: truths that were certain at the time and the object of international attention were transformed into speculation, rumours and uncertainties. The initial denials entered collective culture in Turkey and slowly became more prevalent outside: the events did not take place; Turkey bears no responsibility for any loss of life; Armenian deaths were an unintentional by-product of bad conditions; the term 'genocide' is not applicable" (2001:134).

The shift from genocide knowledge as "truth" to its categorization as "uncertainty" and "speculation" poses a challenge to the sociology of knowledge. Who turned "truth" into "uncertainty"? Why and by what means? Was Halbwachs's notion of presentism at work? Who adjusted knowledge to new circumstances, and how? Further, in light of early changes, how can we explain the later solidification of knowledge, the relative inertia of memory?

The explanatory puzzle posed by Cohen is especially pronounced because denial costs Turkey dearly. Bayraktar (2010) rightfully stresses that Turkish denial contrasts with widespread and growing acknowledgment of various historical atrocities around the globe, encouraging official apologies by heads of state for crimes against humanitarian law and human rights norms committed in the name of their countries (see also Bilder 2006). Bayraktar finds Turkish denial of events that unfolded over one hundred years ago even more peculiar in light of modern Turkey's efforts to distance itself from the Ottoman Empire, at least until recently. 
Göçek adds to the puzzle, highlighting that, in addition to symbolic costs, Turkey also pays a substantial material and political price: "millions of dollars to prevent other countries from employing the term 'genocide"' (2015:2), a closed border to Armenia with its military risks and barriers to economic development, and the impediment genocide denial poses to membership in the European Union. Why, then, is Turkey willing to pay such a high price in the currency of challenged legitimacy, loss of international prestige, and economic cost?

Thankfully, recent literature provides rich material with which to reconstruct, in condensed form, the evolution and state of Turkish knowledge about the mass violence against the Armenians. It suggests several answers to questions raised above about the conditions of knowledge, its mutations, and later inertia. I seek to show how these answers correspond with, benefit from, and contribute to the sociology of knowledge approaches discussed thus far.

Knowledge entrepreneurs play a central role, for which Fatma Müge Göçek’s (2015) book Denial of Violence: Ottoman Past, Turkish Present, and Collective Violence against the Armenians, 1789-2009 provides crucial evidence. Göçek's analysis of the evolution of Turkish knowledge about the country's violence covers more than a century, divided into four eras. The ensemble of more than three hundred memoirs of prominent Turks she analyzed allows for the construction of a gestalt of collective knowledge as property of those segments of Turkish society that were motivated and able to write such texts. Exceptions notwithstanding, factual denial and, especially, interpretive and implicatory denial were prevalent. They played out especially in the immediate post-World War I era (see also Kaiser 2003).

Further, news media and textbooks diffused knowledge produced by elites to a broad public, and for this, too, recent scholarship provides a wealth of evidence. Seyhan Bayraktar (2010) analyzes Turkish newspapers and their statements pertaining to the Armenian genocide (1973-2009), and several authors examine Turkish textbooks (Adak 2016; Akçam 2014; Wolfgram 2019). Together, memoirs, news media, and textbooks reveal the state of Turkish knowledge about the treatment of Armenians during World War I. Each of the authors cited also provides causal arguments that correspond with and enrich a sociology of knowledge perspective. Consider the sedimentation of knowledge regarding the genocide against the Armenians over four periods Göçek (2015) distinguishes.

\section{THE YOUNG TURK ERA (1908-1918)}

Accounts of Turkish knowledge about the Armenian genocide during the Young Turk era, an era that includes the war and the execution of mass violence, are fraught with ambiguities. Recognition is accompanied by denial, repression of information, silencing, media control, and various forms of neutralization, from blaming the victim to attributing responsibility to the Great Powers. Memoir writers, 
especially Young Turks and members of their administration, are motivated to shape, in an exculpatory manner, public understanding of the events to which they contributed. Like all political leaders, they hope to go down in history as heroes, and they certainly want to dispel any thought of criminal responsibility. They are also in institutional positions to reach a broad audience, and some master substantial narrative facility, capturing ideas in a narrative form that is convincing to many.

\section{Narrating Violence in Memoirs}

Early memoirs acknowledge mass violence. I quoted, in chapter 1, from Ahmed Refik's account of the fate of Armenians during the deportations, written shortly after the end of the Young Turk period (1919). Refik described the mournful state of ten thousand to twenty thousand deportees, waiting at the train station of Eskişehir, a "flood of disaster and death" (in Göçek 2015:152), victims of "theft and plunder" whose "houses were burned down to cover their [the perpetrators'] illegal acts" (in Göçek 2015:153). I repeat an earlier quote from this text: "No government at any historical period has committed murders with such cruelty" (in Göçek 2015:153). Yet even Ahmed Refik relativizes by equating violence against the Armenians with violence committed by Armenians against Turks. The title of his book, Two Committees, Two Massacres, indicates as much. By "second" committee and massacre he means "the massacres the Armenian revolutionary committee Dashnak committed against the Muslims in 1918 from Erzurum all the way to Trabzon" (in Göçek 2015:154). Refik disregards the massive difference in the scale of violence committed by the two sides, which Göçek depicts as "deaths of up to 60,000 Muslims ... [versus] at least 800,00o Armenians” (Göçek 2015:250).

Ahmed Refik is not the only Turkish official to have acknowledged the mass violence. A government inspector, also stationed in Eskişehir, writes how houses "had been blockaded, hundreds of Armenian families had been loaded onto carriages, and [many] dumped in streams. Many women witnessing these atrocities had lost their mind" (quoted in Göçek 2015:220). The mayor of Kayseri, a Committee of Union and Progress (CUP) member, describes in detail the organization and staffing of units that were to drive the Armenian population from their villages into collection centers in larger towns (Göçek 2015:221; for a literary account, see Werfel [1936] 1983:152ff). An Ottoman officer describes deportations he observed when traveling to Damascus. He saw "on the two sides of the road unburied corpses of those among the refugee convoys who had fallen sick and died" (in Göçek 2015:223). Four Ottoman Turkish officials describe the Armenian deportations from Diyarbekir (Göçek 2015:224), and ten contemporaneous accounts portray the "deportations and massacres in Aleppo, Damaskus, and Syria ... in great detail" (Göçek 2015:225). Yet such recognition of mass violence and suffering, and occasional expressions of empathy, pity, and regret, are rare compared to instances of denial with its various strategies.

Denialist strategies are, of course, not unique to perpetrators of the Armenian genocide. I showed (in chapter 1) how Raul Hilberg ([1961] 2003) details, for the Holocaust, ways in which actors at different levels of hierarchy managed to 
overcome moral scruples against the execution of atrocity that had been inculcated by a long civilizing process. Within an arsenal of defenses, he distinguishes mechanisms of repression and rationalization. The former include hiding the ultimate aim by controlling information, prohibition of criticism, elimination of the destruction as a subject of conversation, and camouflaged vocabulary. Mechanisms of rationalization, comparable to Sykes and Matza's (1957) neutralization strategies, include a collective form: the justification of the destruction process as a whole, typically achieved by defining the targets as evil. They further include, at the individual level, references to the doctrine of superior orders, insistence that no personal vindictiveness was involved (e.g., the telling of stories about "good deeds" toward Jewish neighbors), blaming others, and attempts to diminish one's own importance in the destruction process.

We find many of these strategies in the Young Turk accounts of the years of mass violence. Consider repression: Göçek reminds us that "the violent and systematic elimination of Ottoman Armenians by the CUP, the government, and state forces was carried out under the legal cover of 'temporary deportations' [i.e., camouflaging vocabulary]" (Göçek 2015:246). Repression by silencing takes two forms. Memoir writers intentionally silence events that did take place, or they omit mention of "the actors involved in secret and informal execution of the collective violence" (Göçek 2015:247). One writer describes the role of Bahaeddin Shakir, the CUP official who implemented Interior Minister Talat's orders on the ground: "This issue was not dissected or illuminated even at the most intimate [CUP] meetings. I do not have a clear, absolute opinion, but from a word used when other issues were being discussed, a thought that leaked out, jests that could not be contained, in summary, from all such fine and slight clues ... he was the greatest motivator and creator of the deportation business" (quoted in Göçek 2015:217).

In addition to repression, neutralization strategies (Sykes and Matza 1957) come to full display, including collective neutralizations that seek to justify the destruction process as a whole (Hilberg [1961] 2003). The government inspector from Eskişehir, cited above, reports the words of a CUP official who, in a speech, compared the Christians in the empire to "snakes and scorpions" (Göçek 2015:220). This language builds on a long tradition in which Ottoman authorities and intellectuals considered Armenians traitors and internal enemies, especially after select groups of militant Armenians cooperated with the Russian enemy during World War I and in previous armed conflicts (Göçek 2015:251). It is also in line with language used in the buildup and execution of other genocides (e.g., Rwanda, Holocaust).

Individual neutralization, partly building on such collective form, appears in memoirs primarily in the form of "blaming the victim." Remember the words of Dr. Mehmed Şahingiray, a CUP and Special Organization member, quoted in chapter 1, who deems it "natural for there to be a danger for the Muslim populace to be carried away by their emotions, reacting in kind to the rapacious and terrible murders of the [Armenian] element with which they had lived for so many 
centuries, considering them [fellow] citizens and brethren" (quoted in Göçek 2015:250).

Göçek observes correctly that the author omits specification of "precautionary measures" (what in fact did the government do?) and that he joins those who falsely equate Turkish and Armenian victimization. In addition, this Young Turk memoir writer blamed the Great Powers (Göçek 2015:246), and he points at a few "black sheep" as responsible for atrocities that even he cannot deny (Göçek 2015:252, 255).

\section{Institutional Position, Motivation, and Popular Receptivity}

Importantly, the Young Turk leaders were not only motivated to deny, they also had the means to spread their denialist narrative. They were knowledge entrepreneurs. A paragraph from Göçek's book makes this point quite clear:

Given the CUP's extensive control of the state, government, and the media, [Interior Minister] Talat had no problem altering the public discourse, claiming that the rumors about the massacres of Armenians in 1915 were "lies and slander the Armenians had started to contrive and fabricate about [some] Turkish and Kurdish massacres." And Talat did so when he had full knowledge that such massacres were occurring, executed mainly by the [Special Organization] armed bands he had personally helped organize and fortify. In 1915 the CUP also published propaganda material to allegedly demonstrate the destructive intent of all Armenians, material originally confiscated by the Ottoman state during the 1893-96 rebellions. (Göçek 2015:248)

The early strategies employed during the peak of the deportations continued as the end of World War I was in sight and CUP leadership had to expect military defeat. Göçek continues thus: "In the aftermath of the Armenian deportations and massacres, the CUP once again published propaganda as early as 1917 and 1918, perhaps due to the limited Armenian massacres of the Turks and Kurds in the east after the withdrawal of the Russian empire from the Great War, leading 'those who had been ashamed by the Armenian deportations to change their views as a consequence of this propaganda, to instead feel animosity toward the Armenians'" (Göçek 2015:248-249).

Göçek also informs her readers about historical conditions that contributed to both the genocide and its denial. She highlights the sultan's modernization efforts, continued by the Young Turks, which lacked a sufficient structural and cultural basis in Ottoman society (Göçek 2015:155-157); the widespread perception of minorities dominating the business world (Göçek 2015:171-172); and the nature of the Young Turks as a movement rather than a formal party. As a movement, they developed a pattern of secrecy, which they imported into government practice after their coup of 1913 under Enver Pasha (Göçek 2015:188). A culture of violence within the CUP supplemented these conditions (Göçek 2015:191, 202), as did the radicalization of the CUP (Bloxham 2005).

One additional factor speaks not just to the motivation of Young Turk leaders but also to the receptivity of the public. Preceding the Armenian genocide, just 
before the outbreak of World War I, the Ottoman Empire had suffered a devastating defeat in the Balkan War of 1912 to 1913. Göçek writes that "the war was disastrous for the empire; it lost 146,100 square kilometers of land, and approximately a million Balkan Turks were massacred or escaped to the empire with nothing but their clothes on their backs. In the end, the population of the empire decreased by 5 million, corresponding to a loss of about a quarter of all land mass" (Göçek 2015:228). The territorial loss was not just vast; it also included the industrially most developed regions of the empire. The Ottoman leaders believed that the Great Powers had promised a return to the status quo of the prewar era, a promise that was not fulfilled; hence, deprived of land, economic capacity, and population, their sense of betrayal was profound. ${ }^{1}$

The defeat in the Balkan War thus damaged the resource base of the empire, the Ottoman leaders' national pride and political ambitions, and the sensitivities of many leading Young Turks who were native to the lost territories. The wounds also dug deep into the lives of ordinary Turks, as "hundreds of thousands of refugees flooded the empire ahead of the Bulgarian army. . . . The Directorate of Refugees kept sending the refugees 'to Anatolia in droves', while at least 40,000 to 50,000 ill and neglected ones remained behind in the capital. With this flood, the populace of the imperial capital also witnessed the trauma of the Balkan Wars" (Göçek 2015:235). Meanwhile, the arrival of masses of refugees in Anatolia intensified competition over scarce resources.

We can only imagine the stories about loss and betrayal circulating among the refugees and their struggle to secure an existence in their new settlement areas. Many Turks were pained even more because these displacements followed, by little more than one generation, those resulting from the Ottoman-Russian wars of $1853-56$ and $1877-78$. The second of these wars especially had already caused substantial loss of territory in the Caucasus and in the Balkans, and it, too, had unleashed a wave of refugees into the empire (Göçek 2015:37). Many Turks' profound suffering and sense of victimhood, we must assume, had lowered their sensitivities toward the victimization and suffering of others, including Armenians during World War I, and increased their receptivity toward denial.

\section{MEMORY FORMATION IN THE EARLY \\ REPUBLICAN ERA (1919-1973)}

The Young Turk era ended with the defeat of the Axis Powers at the end of World War I. In Germany, the emperor was forced into emigration, and the foundation for the short-lived Weimar Republic was laid. The formerly mighty Austro-Hungarian Empire split into small nation-states, and the imperial capital of Vienna suddenly seemed out of proportion to the now modest Alpine republic of Austria. Finally, the long history of the Ottoman Empire had reached a shameful and degrading end. Large parts of its territories were occupied by the victorious powers. 
What were the conditions for the development of knowledge about the Armenian genocide in this new context, specifically in the early republican era of the new Turkey? Here too, Göçek's analysis of memoirs contributes answers. Marking the beginning of this era with the 1919 onset of the Turkish independence struggle, she considers the war crimes trials of the early postwar era (1919-1922) and the establishment of the Turkish Republic on October 29, 1923, extending this period to include the end of the first half century of the republic's existence. Examining her account through the analytic categories laid out above yields further insights for the sociology of genocide knowledge.

\section{Criminal Trials: Failures of an Otherwise Powerful Cultural Tool}

In response to pressure from the victorious Allies, the postwar Turkish authorities initiated and held criminal trials of some actors whom they suspected of having perpetrated violence against the Armenians and of other mass atrocities. Sociolegal theory and empirical evidence from a variety of postwar and post-dictatorship trials suggest that such trials should have generated Turkish recognition of the atrocities. Arguments by Émile Durkheim, further developed in recent sociological literature, consider trials powerful rituals that awaken society's conscience, highlighting and generating a collective understanding and condemnation of evil. This literature interprets criminal punishment as a didactic exercise, a "speech act in which society talks to itself about its moral identity" (Smith 2008:16). The representational power of trials became most visible a quarter century later, through the proceedings of the International Military Tribunal at Nuremberg, which initiated the extension of knowledge of the Holocaust and broad psychological identification with the victims (Alexander 2004). Supplemented by the Eichmann trial in Jerusalem and the Frankfurt Auschwitz trial, these court proceedings produced cultural trauma as members of a world audience developed empathy with suffering they had not experienced themselves.

Not only sociologists, but legal and political practitioners as well have invested much hope in post-violence trials. Prominently, both President Franklin D. Roosevelt and the American chief prosecutor of the Nuremberg trials, Justice Robert Jackson, hoped that the trial-by laying out all the evidence, both written documents and the testimony of witnesses under oath-would certify knowledge, beyond reasonable doubt, of the unbelievable acts Nazi Germany had committed (Douglas 2001).

Trials can indeed serve such a function, even if constrained by a particular institutional logic. Examples abound, as documented in scholarly works on the Frankfurt Auschwitz trial (Pendas 2006), the Nuremberg "Doctors' trial" (Marrus 2008), the My Lai trial (Savelsberg and King 2011), and trials held by the International Criminal Tribunal for the former Yugoslavia (Hagan 2003; Savelsberg and King 2011). A recent example is the impact on Western public opinion generated by criminal charges filed against perpetrators of the Darfur conflict in Sudan, all the way up to the country's (then) president, Omar al-Bashir (Savelsberg 2015; Savelsberg and Nyseth-Brehm 2015). 
Yet the trials held in Constantinople between 1919 and 1922 had no such effect. Instead, they stood at the beginning of a period in which denial of the Armenian genocide solidified, and in which former perpetrators were celebrated as heroes of the independence struggle. These trials thus constitute a challenge for the sociology of law and knowledge. What features of the Constantinople trials, and what contextual conditions, contributed to this unexpected outcome?

Some of the context and the constraints under which these trials were conducted become evident through Göçek's description of the judicial proceedings, for which she again provides evidence contained in contemporaneous Turkish memoirs. Challenges associated with setting up the trials included the issue of national sovereignty, which the Allies resolved by allowing the Ottoman authorities to conduct the trials, and legal ambiguities resulting from the informal ties between the Ottoman government and the CUP on the one hand and the illegal, and nonpublic, actions of the Special Organization on the other. These conditions posed substantial impediments in identifying suitable defendants.

Once the court began its work on December 16, 1918, the challenges intensified. First, the court faced fierce resistance. Memoirs document how former CUP members, now in positions of authority, obstructed the trials by warning friends, slowing the flow of correspondence, and destroying documents: "In our sleepless eyes, half drowned by the smoke and dripping with tears, the flames of the things we burned started to take on the color of blood. And we constantly burned the strange thing we call the past" (in Göçek 2015:357). CUP and Special Organization members further sought to obstruct proceedings by infiltrating offices of the Allied forces. They finally sought to delegitimize the courts through media commentaries that linked the trials to the occupation by foreign powers.

Second, politicization of the trials posed a challenge. Unionists, following in the CUP's footsteps and seeking to create an ethnically pure Turkish nation, charged that the Ententists, who pursued the continuation of a multiethnic empire and who constituted the government in the postwar years, cooperated with the occupiers, therefore engaging in a witch hunt against former CUP officials.

Thirdly, and most importantly, multiple efforts to delegitimize the military tribunal and to rehabilitate the perpetrators posed challenges. One memoir writer described the judge as "an enemy of the Turks" (quoted in Göçek 2015:360). Challengers of the court celebrated their greatest successes when the court also sentenced nationalists in absentia.

In the course of the court proceedings, the populace, in its nationalist fervor, and encouraged by Unionist leaders, began to redefine perpetrators as heroes who fought for the country's liberation from the occupying forces. Several memoir writers, in fact, tied the independence struggle to the trials, condemning those who sought to punish the perpetrators of the Armenian genocide. One writer explicitly linked the trials with prominent Armenian actors and their political, and territorial, pursuits: "The one gathering, readying, and transporting the witnesses [to the tribunal] is the (Armenian) Patriarchate. The Armenians are after 
Greater Armenia, some ... after a Kurdistan next to this Armenia, the Greeks after Smyrna, Thrace, and a Pontus Kingdom on the Black Sea shores" (quoted in Göçek 2015:360).

The most convincing evidence of the attempt to cleanse the record of perpetrators results from Göçek's detailed effort to trace the fate of different categories of suspects. Those arrested, charged, and acquitted contributed memoirs that "selectively narrated their past violence, providing irrelevant information while silencing their actual acts of destruction" (Göçek 2015:361). A second category were those the British had exiled to Malta and Egypt, in reaction to mass protests against the first conviction and the hanging of the convicted. Eventually, they were allowed to return to Turkey, in exchange for British citizens who had been sequestered in the empire. Many of these former exiles later became prominent republican politicians. Those among them who wrote memoirs never mentioned the violence against the Armenians or the role they had played in the genocide. Yet another group consisted of those who had escaped arrest, fled to Ankara (outside the reach of the occupying forces), and joined the independence struggle. "They were all very well received in Ankara because the leaders of the independence struggle needed educated CUP officials, officers, and civilians and therefore did not hold the perpetrators' crimes against them" (Göçek 2015:371).

A final category consists of those who were tried and hanged or otherwise killed. Many memoir writers celebrated them as "national martyrs" (Göçek 2015:365). Given the impediments the court faced, their number was quite small (fewer than ten). The redefinition of their reputation began right after the death sentence and execution of Kemal Bey, which shocked those who were imprisoned and awaiting trial but expecting lenient treatment. They and their loyalists' desperate desire to redefine perpetrators as martyrs was helped by the trial against Nusret Bey, in which the court offended against rules of procedure, and-mindful of potential challenges-sped up the convict's execution.

Summarizing this event in the context of judicial (non-)responses, Göçek writes that

the rationalizing event comprising the few injustices committed at the 1919-22 military tribunals coincided with the independence struggle, enabling the nationalists to gradually transform the former perpetrators into patriots, thereby leaving only a few to be held accountable for the crimes they committed against the Armenians. The majority not only avoided prosecution but escaped to Anatolia to join the independence struggle, and with the victory of the struggle, they reemerged as republican patriots and served the newly established nation-state in high positions. This transformation effectively produced the republican denial of the perpetrators of the collective violence against the Armenians. (Göçek 2015:373)

In short, against Durkheimian expectations and despite positive historical evidence for other post-atrocity trials, the court proceedings in Istanbul did not affirm the history of the Armenian genocide. Instead, the trials strengthened the 
notion of Armenians as aggressors and the redefinition of former perpetrators as national heroes. Collective amnesia about the victimization and suffering of the Armenians during World War I was the ultimate consequence. The ritual power of trials is contingent, as this experience certifies, on the legitimacy of courts, and circumstances described in this section thoroughly undermined such legitimacy.

\section{Strategies of Denial: Historical and Personnel Decoupling}

Following the immediate postwar period and the trials, denial unfolded in two stages. Memoir writers first engaged in what we might call historical decoupling. They denied any connection between the independence struggle and the CUP. Nationalist leaders used various strategies. The CUP itself held back the publication of individual memoirs by its leaders in the years immediately following the war (Göçek 2015:375). Leaders blocked the return of CUP top leaders from exile (Göçek 2015:378), and they obscured the continued presence of CUP membersfirst in the liberation struggle and later in the new republic-and obscured their identities (Göçek 2015:379). A famous 1927 speech by Mustafa Kemal (Atatürk) was crucial. In that speech, he skillfully hid the role of the former CUP in the independence struggle, portraying himself as the undisputed leader of the movement and the new republic (Adak 2003). Many memoirs show that this definition of the new Turkish reality conflicted with the actual historical situation.

A second stage of denial silenced the involvement of perpetrators in the republican cadres, which I refer to as personnel decoupling. Nineteen memoirs analyzed by Göçek confirm the continued presence of former CUP members as civil servants in the new republic. Many among them swore an oath not to inform on each other. One memoir writer determines that November 1920 was a turning point. At that time all former perpetrators, CUP and Special Organization members, joined the independence struggle under the condition that they be granted amnesty. "The allied forces and the destroyed non-Muslims had indeed noted and protested the Unionists amid the national forces, but this did not change the future course of events because in the end, they were forced to leave, and the national movement ultimately succeeded. The subsequent national history of Turkey was penned by the winners who whitewashed the past violence against the Armenians as well as the violence they committed in achieving their victory" (Göçek 2015:381).

Additional strategies supplemented and solidified new knowledge repertoires: exclusion of contributions that Armenians and other minorities had made to the Ottoman Empire, and the cleansing from history of the mass violence committed against these populations. Toward that end, state authorities renamed parks and squares and confiscated Armenian property, turning some buildings into schools and theaters.

Perhaps most consequentially, the new republican government introduced changes to the educational system. Republican leaders decided early on to 
centralize all educational institutions under the Department of Education in Ankara. The department controlled textbook production, teacher training, course content, and examination questions. Textbooks harmonized closely with official nationalist rhetoric. The curriculum highlighted Turkish contributions to the country's development and the righteousness of Muslim Turks, at the expense of other religions and ethnicities. These patterns transcended that era and survived into the late republican period, as an analysis of recent Turkish textbooks shows (Akçam 2014; also Adak 2016; Wolfgram 2019). Political controls reached beyond primary and secondary education to encompass institutions of higher learning. Constraining critical engagement with Turkish history, they tightened in specific moments such as the 1960 military coup. Göçek concludes that "the ensuing system produced public knowledge that instituted, diffused and reproduced Turkish ethnic nationalism, distorting the past and erasing the presence in and contributions of non-Muslims and non-Turks to Turkish history. . . In summary, early republican modernity, undertaken with the intent to democratize the country and successfully transform former Ottoman subjects into Turkish citizens, instead produced a society hegemonized by the Turkish state and government in particular and the dominant Turkish majority in general" (Göçek 2015:294-295).

Consequently, memoirs written by leading politicians and administrators of the CUP shortly after World War I, but published only decades later, self-celebratory and self-exculpatory, fell on fertile ground. Authors included Talat Bey (Minister of the Interior) and Djemal Bey (Minister of the Navy), both members of the triumvirate of Young Turk rule, and lower-ranked but powerful actors such as Ali Münif, whose career reached from serving as Talat's undersecretary to becoming governor of Lebanon and Beirut $(1915,1916)$. All were highly motivated to present to their readers a clean and heroic Turkish past, and all mobilized substantial narrative facility to eliminate knowledge of the atrocities they had committed during their reign, or-where elimination was not an option-to justify their actions (Kaiser 2003).

\section{LATE REPUBLICAN KNOWLEDGE FORMATION (1974-2009)}

The year 1974 marked the beginning of a new era of Turkish denial, in response to a global and intensifying Armenian insistence on acknowledgment of the genocide. Destabilizing domestic events sharpened Turkey's reaction. Importantly, in 1973 the conservative wing of the military had intervened in the political process, resulting in a substantial tightening of civil liberties. In the following year, the Turkish military launched an offensive in Cyprus. Turkish troops occupied 40 percent of its landmass, setting off waves of refugees and an exchange of Greek and Turkish populations to split the island into two parts (Bayraktar 2010:99-103).

Simultaneously, a new cultural climate provided fertile ground for the emergence of terrorist organizations across the Western world. In Germany, the Baader-Meinhof group engaged in abductions and killings of prominent 
politicians and business leaders; in Italy, the Brigadi Rossi pursued similar strategies; and in the United States, groups such as the Symbionese Liberation Army spread terror. In Palestine, Israel, and beyond, the Palestine Liberation Organization (PLO) engaged in terrorism to pursue its goals. It was in this context that members of radicalized Armenian diaspora groups resorted to terrorist strategies. Leading among them was the Armenian Secret Army for the Liberation of Armenia, organized in Beirut and operating in collaboration with the PLO, presumably with support from the Kurdish Workers' Party and the Irish Republican Army (Bayraktar 2010:98). Around the same time, a group named Justice Commandos of the Armenian Genocide, founded in the United States, also took up arms.

Establishment of these organizations resulted in a decade of terrorist violence. The series of murders was initiated, however, by the violent act of an individual. In 1973, Gurgen Yanikian, a seventy-seven-year-old immigrant from Turkey to the United States, who had lost many members of his family during the violence of 1915, assassinated the Turkish consul general to Los Angeles (Mehmed Baydar) and his deputy (Bahadır Demir) (Bayraktar 2010). In a letter to various American newspapers, Yanikian wrote that he wanted to avenge the genocide, and he called on other Armenians to follow his example. Göçek (2015) spells out the deadly harvest: "a total of 110 acts of terror against the Turkish republic in thirty-eight cities of twenty-one countries. Of these, 39 are armed attacks, 70 are bomb attacks, and 1 is an occupation. During these attacks, 42 Turkish diplomats and 4 foreign nationals are murdered, and 15 Turks and 66 foreign nationals are wounded" (Göçek 2015:46-47). This wave of violence against Turkish targets reached its peak in 1979 and finally ebbed in 1986.

Armenian terrorist activities succeeded in breaking Turkish silence about Armenian history (Bayraktar 2010:97). Yet, against the intent and expectation of the terrorists, they did not yield acknowledgment. On the contrary, the violence provided Turkish authorities with new bricks to build their wall of denial and to appeal to the Turkish public at home and the Turkish diaspora abroad. Turkish state actors used Armenian terrorist violence to engage in reverse analogical bridging: to color the interpretation of all past violence in ArmenianTurkish relations in light of the present. Current terrorism aided their interpretation of past Armenian violence as aggression and Turkish violence as defense. Göçek concludes:

In a defensive move that commenced in 1981, Turkish state officials in general and the diplomats in the Foreign Ministry in particular developed an official counternarrative that actually delegitimated and negated the Armenian claims. These officials selectively focused on the past, homing in exclusively on the incidents of Armenian violence to thereby portray the Turks not as perpetrators but as victims. As a consequence, it became easier to argue that what had occurred in the past had been 'mutual massacres.' By doing so, however, the Turkish official stand actualized the last stage of denial, namely, the denial of responsibility for the collective violence committed against the Armenians. (Göçek 2015:456-457) 
Narratives of historical processes cannot easily establish causality. Would Turkish denial not have succeeded and further solidified without the wave of Armenian terrorism in the 1970s and 1980s? We do not know. Yet we do know that Turkish discourses on Armenian history were revived at this juncture. They built on past practices of denial and further advanced the sedimentation of Turkish knowledge. Göçek's analysis of memoirs shows that much.

Critical readers may challenge Göçek's account of Turkish denialist representation, noting that it relies primarily on one type of document. They may ask whether memoirs merely reflect knowledge within a small group of actors in positions of authority and in the intelligentsia. Such critics, however, should not overlook analyses, by Göçek herself and other scholars, of news media and textbooks, which are crucial mechanisms through which knowledge entrepreneurs reach a broad audience and pass knowledge on to new generations.

\section{Diffusing Knowledge: News Media}

Turkish news media indeed reinforce dominant themes from the memoirs Göçek analyzed, as findings by Seyhan Bayraktar (2010) convincingly demonstrate. Bayraktar analyzed 1,339 Turkish media reports, published between 1973 and 2009, from five distinct newspapers. Included in her sample are the nationalist, populist, and military-friendly Hürriyet; the left-leaning, radically secular, and somewhat elitist Cumhuriyet; the Islamist-fundamentalist Milli Gazete; the liberal Radical; and the Islamist-conservative Zaman. Bayraktar selects articles specifically addressing "critical discourse moments", historic events that evoke broad public debates about Turkish history.

Working to identify frames through which Turkish media interpret Armeniarelated events, Bayraktar first finds a terrorism frame. Reporting on Armenian terrorist activities, media juxtapose "innocent diplomats," good people who dutifully served their nation, to "cold-blooded Armenians" (Bayraktar 2010:106). Yanikian, the initial individual assassin, is portrayed as "vengeful," "uncivilized," and "crazy." Media reports omit, or mention only in passing, his traumatic experiences of 1915 . Armenians are "notorious terrorists." One commentary proceeds to link the killing of the Turkish consul-general to the 1921 assassination of Talaat Pasha by a young Armenian, Soghomon Tehlirian, in Berlin (Bayraktar 2010:109). Media also represent Yanikian as a member of the "Huntschak" organization, thereby linking his action to the violent Armenian resistance movement of the 189os (Bayraktar 2010:111).

Following highly organized terrorist attacks against the Turkish embassies in Vienna and Paris in the fall of 1975, the interpretive frame in Turkish news media shifts from "Armenian" to "international" terrorism. On October 25, 1975, Cumhuriyet quotes Prime Minister Süleyman Demirel's words in its headline “Turkish State Target of Murders" (Bayraktar 2010:112). Media reports are careful, however, to interpret the Armenian terrorists as members of the diaspora, 
contrasting them with "our Armenians" (Bayraktar 2010:115). Such distinction seeks to present domestic Turkish-Armenian relations as harmonious. It also aims to prevent a recurrence of Turkish pogroms akin to those against Greeks in 1955 that had caused major destruction and bloodshed. Yet not all papers apply such caution. Milli Gazete more aggressively writes about "minorities in our country that have, throughout our history, pushed the knife into the back of the nation. The minorities include Greeks and Armenians" (Bayraktar 2010:116). ${ }^{2}$

Other media reports reflect more explicitly on Ottoman-Armenian relations throughout history, including the violence of 1915. Milli Gazete writes about "The Massacres by Armenians in our History," and a five-part series in Hürriyet is entitled "The Truth behind the Armenian Question" (Bayraktar 2010:121). This series reads like a "treatise on Armenian revolts, collaboration and instrumentalization by foreign powers" (Bayraktar 2010:212). Its authors attribute responsibility for violence primarily to "radicalized" Armenian organizations and political parties such as the Huntshaks and Dashnaks. In addition, they seek to identify foreign powers as responsible for the decline in Ottoman-Armenian relations: Armenians "dared to engage in the revolts only because they had the back of the European powers" (in Bayraktar 2010:125). Thus, the series concludes, Turks and Muslims are the real victims of history: "Millions of innocent Turks ... were killed during the Armenian massacres. ... Yet, Armenians received the appropriate response. . . They had to receive that response as there are two things Turks cannot tolerate: injustice and cowardly actions" (in Bayraktar 2010:125).

In short, terrorist violence, motivated by rage about Turkish denial of the Armenian genocide, provided the Turkish government and media with ammunition to advance denial further. It helped knowledge entrepreneurs strengthen, at least domestically, Turkish interpretations of the violence of 1915.

A decade and a half later, another historical moment evoked Turkish media engagement with Armenian history. In 1991, Armenia once again became an independent country. After separating from the dissolving Soviet Union, the new republic joined diasporic Armenian communities to push for recognition of the genocide at national and international organizational levels. A new knowledge entrepreneur had thus entered the scene, and a growing number of countries now recognized the Armenian genocide (see chapter 7). Such recognition evoked massive governmental and societal responses in Turkey, where sensitivities were heightened in the context of the country's new status, in 1999, as an official candidate for membership in the European Union.

Challenged and sensitized, Turkey intensified denial. In response to a 2001 French genocide recognition law, Hürriyet's chief editorial writer, Oktay Ekşi, calls for a general boycott of France by Turkish organizations and businesses. Generally, papers express alarm regarding the spread of the "recognition virus" (Bayraktar 2010:202). Using its geostrategic position vis-à-vis the Middle East and Incirlik Air Base (shared with NATO allies) as a bargaining chip, Turkey 
manages to prevent U.S. recognition of the genocide. Media now open a new line of attack, charging European powers with their own complicity or guilt. Milli Gazete reminds its readers that France continues to pay pensions to Armenian veterans (Bayraktar 2010:206), and Cumhuriyet, responding to a pending debate of the Armenian genocide in the German legislature (Bundestag), quotes a leading Turkish foreign policy maker who charges Germany with the attempt to relativize the Holocaust. ${ }^{3}$

Eventually, however, Turkey recognized that its version of the events of 1915 was no longer internationally accepted. Armenians had spread, in the words of a commentator in Milli Gazete, a "lie for a truth" (Bayraktar 2010:211). Journalists now redirected their writings, as in a commentary in Cumhuriyet, against a three-phase plan: recognition, reparation, territorial demands (Bayraktar 2010:212, 216). They also reminded the world of histories of atrocities committed by European powers, including French violence in Algeria, and challenged European "claims of cultural superiority" (Bayraktar 2010:220).

In short, media discourses analyzed by Bayraktar raise similar themes as the memoirs Göçek dissects. Both types of documents generate Turkish knowledge about Armenians and the Armenian genocide. Both involve factual and interpretive denial. Well-known neutralization strategies of blaming the victim and challenging the accuser support such denial (Sykes and Matza 1957). Journalists join government officials and intellectuals in articulating and reinforcing denial of the Armenian genocide.

\section{Intergenerational Transmission of Knowledge: Textbooks}

Textbooks do not just reflect knowledge; they communicate it to new generations. The Department of Education in Ankara produces or approves all textbooks, and these textbooks, not surprisingly, reflect official Turkish positions on topics such as the Armenian genocide. Clashing with historical scholarship and radically opposed to Armenian knowledge, they simplify to the extreme. Easily identifiable errors abound (Akçam 2014; Adak 2016; Wolfgram 2019:175-180).

Textbook narratives, like other contributors to cultural trauma, identify the nature of the pain, the nature of the victim, the relation of the trauma victim to the wider audience-and they attribute responsibility. Yet here the account is reversed, advancing cultural trauma about Turkish suffering and victimization. A middle school textbook, approved by the Ministry of National Education's Board of Instruction and Education on December 8, 2011, addresses the "The Armenian Events." It teaches students about Armenian rebellions, initiated by revolutionary organizations. In this narrative, rebels issued instructions to fellow ethnics according to which "if you want to survive you have to kill your neighbor first" (quoted in Akçam 2014). ${ }^{4}$ Consequently, "Armenians murdered 'many people living in villages, even children, by attacking Turkish villages, which had become defenseless because all the Turkish men were fighting on the war fronts. . . . They stabbed 
the Ottoman forces in the back. They created obstacles for the operation of the Ottoman units by cutting off supply routes and destroying bridges and roads... . They spied for Russia and by rebelling in the cities where they were located, they eased the way for the Russian invasion" (in Akçam 2014).

Another textbook, written for the tenth grade and approved on May 4, 2009, addresses the events of 1915 under the heading "The Armenian Problem during the World War I Years." It explains to students that "the entry of the Ottoman state into World War I was viewed as a great opportunity by Armenians. . . . $[B] y$ invading Erzurum, Erzincan, Mus, and Bitlis in Eastern Anatolia, Russia further incited the Armenians in these regions" (in Akçam 2014). This account misses the fact that Russian military invaded the cities listed here only beginning in April 1916, after the deportation of the Armenian population.

Elsewhere, textbooks teach Turkish students that deportations actually sought to protect Armenians from radical-militant Armenian groups, that agricultural opportunities were prepared for resettled Armenians, and that police stations were set up at the places of destination to protect them from violence. The relative size of victimization, as well, deviates gravely from that identified by mainstream scholarship: "[B] ased on figures from unbiased researchers, 300,000 Armenians lost their lives due to war and sickness. . . . [Yet,] according to official Russian records ... Armenians killed around 600,00o Turks in just Erzurum, Erzincan, Trabzon, Bitlis, and Van and forced 500,000 . . . to migrate" (textbook quoted in Akçam 2014). ${ }^{5}$

In short, Turkish textbooks describe much suffering, manifold deaths, and displacement of populations. Yet the victims are primarily Turks and those Armenians who did not heed the call of their radical brethren to kill Turks. Responsible for the violence are either Armenians generally, radical Armenian organizations, or foreign powers. At times, textbooks present Armenians as internal enemies who betrayed their own country (the Ottoman Empire) to foreign powers. The basic structure of Turkish textbook narratives is thus consistent with that identified for memoirs and media. As is common in textbooks, the narrative is simplified. The contours are yet more starkly recognizable than in the other types of documents. Turks as a carrier group, with the Turkish state as a powerful knowledge entrepreneur, thus recharge sedimented knowledge to transmit it to new generations.

\section{COMPARATIVE PERSPECTIVES: ARMENIANS, TURKS, AND THE USHMM}

Karl Mannheim, one of the founders of the sociology of knowledge, believed that the examination of knowledge carried by collectivities with different positions in social life, and thus with different viewpoints, could help scholars approximate that which constitutes truth. Contemporary scholarship no longer shares his 
hope. Today, the sociology of knowledge limits itself to analyzing and explaining varying and potentially clashing sets of knowledge, and possibly to examining their consequences. The truth about the Armenian genocide thus does not lie somewhere between Armenian and Turkish knowledge. Nor do we arrive at a more objective truth if we add yet other perspectives that are not carried by the adversarial groups.

Nevertheless, comparing Armenian and Turkish depictions of history, and juxtaposing them with knowledge generated by other actors and in the realm of scholarship, holds some analytic benefit. At the least, it alerts us to ways in which each-Armenian knowledge and Turkish knowledge-varies not just from the other, but also from outsider knowledge, generated under conditions that differ from those characteristic of the worlds of Armenians and Turks.

Armenians dominate among those who curate exhibits and establish memorials to the Armenian genocide. The Tsitsernakaberd Memorial Complex in Yerevan and the 2015 exhibit at the Shoah Memorial in Paris are but two examples (chapter 4). While the latter did not take place in an Armenian institution, the curators were prominent Armenian scholars. How does knowledge communicated at these two sites compare with that provided by institutions not associated with Armenians? I select a detailed entry from the website of the United States Holocaust Memorial Museum (USHMM) as a point of comparison. ${ }^{6}$ I ask simultaneously how knowledge transmitted by this site compares to Turkish knowledge.

An extended quotation from the USHMM site's entry on the Armenian genocide indicates that the narrative bears close similarity to, but also noticeable distinctions from, the Armenian representations we encountered above, and that-by implication-it radically clashes with Turkish knowledge. The USHMM site states: "The Armenian genocide refers to the physical annihilation of ethnic Armenian Christian people living in the Ottoman Empire from spring 1915 through autumn 1916. There were approximately 1.5 million Armenians living in the Empire. At least 664,000 and possibly as many as 1.2 million died during the genocide. Armenians call these events Medz Yeghern (the great crime) or Aghet (catastrophe)." Following this quantification of victimhood and sections with historical background information, the narrative continues thus:

Taking orders from the central government in Constantinople, regional officials implemented mass shootings and deportations, assisted by local civilians. ${ }^{7}$ Ottoman military and security organs and their collaborators murdered the majority of Armenian men of fighting age, as well as thousands of women and children. During forced marches through the desert, convoys of surviving elderly men, women, and children were exposed to arbitrary attacks from local officials, nomadic bands, criminal gangs, and civilians. This violence included robbery (e.g., stripping victims naked to take their clothing and conducting body cavity searches for valuables), rape, abduction of young women and girls, extortion, torture, and murder. . . . Although the term genocide was not coined until 1944, most scholars agree that the mass murder of Armenians fits this definition. 
TABLE 1 Comparison of Three Repertoires of Knowledge along Analytic Dimensions (based on memoirs, media reports, exhibits, textbooks, speeches)

\begin{tabular}{|c|c|c|c|}
\hline \multirow{2}{*}{$\begin{array}{l}\text { Dimension } \\
\text { of Violence }\end{array}$} & \multicolumn{3}{|c|}{ Three Sets of Knowledge } \\
\hline & Armenian & Turkish & USHMM \\
\hline Suffering & $\begin{array}{l}\text { perished; massacred; } \\
\text { tragic and violent } \\
\text { dispersion; first } \\
\text { genocide of the } \\
\text { 20th century; } \\
\text { concentration camps; } \\
\text { akin to Holocaust; } \\
\text { Deir ez-Zor predecessor } \\
\text { to Auschwitz }\end{array}$ & $\begin{array}{l}\text { Initial: flood of disaster } \\
\text { and death; theft and } \\
\text { plunder; houses burned } \\
\text { down; deported, } \\
\text { drowned; illness } \\
\text { and death during } \\
\text { transportation } \\
\text { Soon: millions killed }\end{array}$ & $\begin{array}{l}\text { physical annihilation; genocide; } \\
\text { murder; robbery; rape; } \\
\text { extortion; torture; abduction } \\
\text { of women and girls; forced } \\
\text { marches; death from starvation, } \\
\text { dehydration, exposure, disease; } \\
\text { holding camps }\end{array}$ \\
\hline Victims & $\begin{array}{l}1.5 \text { million Armenians; } \\
\text { Armenian populations; } \\
\text { the Armenian people }\end{array}$ & $\begin{array}{l}\text { Early: Armenians and } \\
\text { Turks } \\
\text { Later: Turks, } 600,000 \\
\text { killed in five cities } \\
\text { alone; 500,000 displaced }\end{array}$ & $\begin{array}{l}\text { ethnic Armenians in Ottoman } \\
\text { Empire, majority of Armenian } \\
\text { men of fighting age; thousands of } \\
\text { women and children; Armenian } \\
\text { population in Anatolia; } 664,000 \\
\text { to } 1.2 \text { million Armenians }\end{array}$ \\
\hline $\begin{array}{l}\text { Responsible } \\
\text { actors }\end{array}$ & $\begin{array}{l}\text { Turkish government; } \\
\text { Turks, the Turks }\end{array}$ & $\begin{array}{l}\text { Early: Armenian } \\
\text { revolutionary } \\
\text { Committee Dashnak } \\
\text { Later: Armenians; } \\
\text { radical-militant } \\
\text { Armenian groups }\end{array}$ & $\begin{array}{l}\text { CUP government, ruling circle, } \\
\text { leadership (specific names); } \\
\text { Ottoman military and security } \\
\text { organs; Special Organization; } \\
\text { regional and local officials; } \\
\text { civilians; nomadic bands; } \\
\text { criminal groups }\end{array}$ \\
\hline Time frame & $1915-1923$ & [not specified] & $\begin{array}{l}\text { 1915; spring } 1915 \text { to autumn } \\
1916\end{array}$ \\
\hline
\end{tabular}

Having thus identified responsible actors and types of victimization, including its identification as genocide, the page specifies the stages of death: "Hundreds of thousands of Armenians died before reaching the designated holding camps. Many were killed or abducted, others committed suicide, and vast numbers died of starvation, dehydration, exposure, or disease en route. While some civilians sought to assist the Armenian deportees, many more killed or tormented the people in the convoys."

The narrative of the USHMM closely resembles that of the Tsitsernakaberd Memorial Complex and, yet more closely, the exhibit at the Shoah Memorial in Paris. Noticeable departures are reflected in the somewhat more cautious death estimate, in the limitation to the 1915-16 period, and in the use of the term holding camps-"concentration camps" in the other exhibits. Yet we find analogical bridging from the Holocaust to the Armenian genocide by the USHMM and a confirmation that the term genocide applies in the judgment of most scholars.

Table 1 juxtaposes the Armenian, Turkish, and USHMM perspectives along a set of analytic dimensions. These dimensions overlap with the categories Jeffrey Alexander (2004) spells out as preconditions of cultural trauma. 
Under the label of "suffering," the USHMM describes all forms we typically read about in scholarly literature: physical annihilation, genocide, the Armenian words that mean "great crime" and "catastrophe," murder, robbery (including via strip searches), rape, abduction of young girls and women, forced marches, arbitrary attacks, killing, death by starvation, dehydration, exposure, and disease. This is in line with terms we find in Armenian exhibits.

Comparing both Armenian memorial depictions and the USHMM text to accounts of suffering in Turkish documents, memorials, media reports, and textbooks requires differentiation between early and later sources. The earliest Turkish sources use similar vocabulary to describe the suffering of Armenians: flood of disaster and death, theft and plunder, houses burnt down, people deported, drowned, illness and death during deportations. Yet, when later Turkish documents cite millions of innocents killed, six hundred thousand in just five cities, and five hundred thousand displaced, the victims are Turks. These sources reference "only" three hundred thousand Armenian deaths, which they attribute not to purposeful violence, but to war and sickness.

Armenian sources identify victims as Armenians, Armenian populations, or the Armenian people. The USHMM site writes similarly about the majority of Armenian men of fighting age as well as thousands of women and children murdered. Yet it also specifies ethnic Armenians in the Ottoman Empire and the Armenian population of Anatolia. It further estimates the death toll more cautiously: 664,00o to 1.2 million, contrasting with the 1.5 million estimated in some Armenian sources.

References to responsible actors also show a stark difference between the Armenian and USHMM sites on the one hand and Turkish depictions on the other. In Turkish sources, we find early references to Armenians and the revolutionary committee Dashnak, and later references to Armenians and to militant Armenian groups. This depiction is in line with the identification of Turks as the primary victims of violence. In line with the summary thus far, the Turkish representation of responsible actors differs sharply from those in Armenian and USHMM sources. Armenian representations typically refer to Turks, the Turks, or the Turkish government. Here, too, the USHMM is more specific. We read about the CUP government, CUP ruling circle, and CUP leadership, and we find references to four specific leaders of the Young Turk regime. Other references are to the central government in Constantinople, the Special Organization, Ottoman military and security organs and their collaborators, regional and local officials, nomadic bands, criminal groups, and civilians.

Finally, periodization varies across the different sets of knowledge. Many Armenian sources refer to the years 1915 to 1923 as the era of the genocide, thereby implicating the new Turkish republic, while most other sources refer to the events of 1915 or 1915 to 1916 , or-in the more specific demarcation by the USHMMspring 1915 to autumn 1916. 
In short, the structure of Turkish knowledge regarding forms of suffering, types and numbers of victims, and responsible actors differs radically from those in Armenian sources or the USHMM website. We simultaneously find finer differences between Armenian sources and the USHMM representation. This should not be surprising, given that group identification and partisanship promote clearcut depictions of social reality. In addition, even if historians played a central role in the construction of Armenian knowledge, Armenian knowledge additionally carries features of collective memory as a ritually reinforced and affectively loaded expression of knowledge about the past. Collective memory differs in this respect from historical knowledge. While not independent of the social location of historians, historical knowledge is shaped less by affective and ritual reaffirmation. It is thus not surprising that the USHMM depiction is closest to historical scholarly knowledge about the Armenian genocide. Historians, after all, agree on the core features of the genocide, even if different schools of historiography variably emphasize as conditions for genocide religion and continuity (Vahram Dadrian), nationalism (Richard G. Hovannisian), demographic engineering (Fuat Dündar, Uğur Ümit Üngör, Taner Akçam), cumulative policy radicalization (Donald Bloxham), or state imperialism and contingency (Ronald Grigor Suny) (for a comparative analysis of these positions, see Der Matossian 2015).

Chapter 4 identified conditions that contributed to the shaping of Armenian knowledge repertoires. In the Turkish case, the decisive mnemonic entrepreneurthe centralized and often authoritarian Turkish state-has been in the most powerful institutional position to spread a narrative of Turkish victimization. Importantly, the motivation of the Turkish state remained strong, as continuities from the Young Turk regime and the violence of the early Turkish republic put the glorious foundation myth of the new Turkey at risk. Finally, Turkish society constituted an ideal sounding board in that Turks too had experienced massive death, suffering, displacement, and humiliation during World War I and preceding wars. Sensitivities were heightened further by Turkey's outsider status in a predominantly Western alliance with Christian roots.

International comparison holds potential for further insights. Turkish denial resembles that of the United States, which also displays massive domestic resistance to facing the evil associated with its foundation (Savelsberg and King 2011, 2015). As in Turkey, where mass violence against ethnic minorities extended into the origins of the new republic, the foundation of the United States was associated with the near extinction of the Native American peoples, settler colonialism, and slavery. Mass violence associated with the creation of countries, however, does not sit well in national foundation myths in the modern era.

In contrast to Turkey and the United States, post-World War II (Federal Republic of) Germany cultivated the memory of evil, albeit with delay. Unlike Turkey, Germany was occupied entirely after the end of the war. The occupying powers held major criminal trials against leading perpetrators. Germany eventually 
gained its independence through economic development and integration into a community of nations, not through armed struggle and in relative isolation as did Turkey. Germany, finally, did not hold the same strong bargaining chip as Turkey, whose military cooperation was crucial to a Western alliance confronted with the instabilities of the Middle East. Western countries thus hesitated for many decades to challenge Turkey's insistence on innocence. A comparative analysis obviously suggests conditions for the motivation and ability of governments to advance revisionist knowledge repertoires about episodes of mass atrocities for which their countries bear prime responsibility.

\section{CONCLUSIONS}

Linking back to the conceptual and theoretical tools laid out in chapter 3 , social knowledge about the Armenian genocide is a property of collectivities in which it is confirmed and reinforced-ethnic Armenians in one case, Turks in the other. Yet carriers of such knowledge are not a monolithic mass. Some dissent, while others act as entrepreneurs who spread and reinforce representations and narratives with particular efficacy. Under specific post-World War I conditions, even criminal trials against some of the perpetrators did not display the knowledgegenerating power known from many other cases.

Organizational actors, especially states, are strong knowledge entrepreneurs. As their interests shift, they introduce new elements into repertoires of knowledge. Chapter 4 showed, for the Armenian case, how the transition from Soviet Armenia to the new independent Republic and the intensification of the NagornoKarabakh conflict resulted in mutations of knowledge. In the Turkish case, the state acted as a powerful knowledge entrepreneur, continuously interested in denial, but under shifting circumstances. Its integration into NATO, Armenian terrorism of the 1970 and 1980s, and Armenian independence in 1991 initiated some, albeit modest, modifications of knowledge. These observations provide cautious support for Maurice Halbwachs's argument about the presentism of collective memory.

Yet, just as some basic features of Armenian memory remain constant, firmly sedimented and reinforced in everyday interactions, the stability of Turkish knowledge is pronounced. It settled in soon after the immediate post-World War I years. The highly centralized, at times authoritarian, state with a strong ideological mission is the core source of denialism, and the history of Turkish suffering generated receptivity in the population. Cracks in the body of Turkish knowledge have appeared only in recent decades, especially among intellectuals. Scholarship cited prominently in this chapter illustrates them clearly, and authors such as Taner Akçam, Seyhan Bayraktar, and Fatma Müge Göçek are but examples, all of Turkish descent, albeit now living outside their country of origin. ${ }^{9}$

The stage is now set for part III of this book. Part I explored how knowledge repertoires evolve and how they are negotiated in everyday interactions. Part II 
showed how they solidify and become sedimented. We also saw how knowledge entrepreneurs intervened in these processes and how different collectivities develop distinct, at times contradictory, sets of ideas about the same event. What Armenians and Turks know about the mass violence carried out in the Ottoman Empire in 1915 and subsequent years presents an astounding example of such contradictions.

Contradictions are likely to erupt in conflict and struggle when collectivities face others with very different knowledge repertoires, especially if that knowledge is central to their identity. How do collectivities act in such situations? Again, sociological traditions provide us with helpful guidance. Some strands of scholarship point to strategies directed at the in-group that do not require conflictual engagement with the antagonist. The Durkheimian tradition alerts us to rituals that tie a community together and reaffirm shared values, norms, and ways of understanding the world. Other scholarly traditions highlight direct confrontation with the antagonist in conflictual processes. Examples, short of the threat of violence, are legislative efforts to acknowledge, and thereby privilege, one set of knowledge over others. Legislation may even aim at the regulation of speech by criminalizing articulations that others perceive as offensive. Law courts may (or may not) apply such laws. In doing so, they respond to concrete disputes between antagonists in struggles over appropriate knowledge or permitted speech.

Both rituals and conflictual engagement with the other are thus crucial in struggles over conflicting knowledge. While scholars typically associate rituals with culture and political conflict with power, cultural strategies and power strategies are certainly not mutually exclusive. Cultural practices, including rituals, involve actors with interests and power, while political and judicial struggles make use of cultural repertoires and mechanisms.

Part III therefore examines conflict and power struggles. We will see that it matters in which social field such struggles are being carried out. Each social field, such as politics or law, is governed by its own rules of the game. Actors in each field have acquired a specific habitus that corresponds with its rules. This habitus includes an immersion in the logic of the institutions that are prominent within each field. Yet there is also room for discretion and improvisation, for a flexible application of the rules of the game. Finally, institutions, nested within fields, take on different shapes across countries. The law works differently in the United States than elsewhere, and politics operate differently in France than in other countries. These particularities are likely to affect the shapes and outcomes of struggles, even in a globalized world.

First, however, I turn to rituals: Durkheimian moments that affirm identities and knowledge repertoires among both Armenians and Turks. Who initiates such rituals? What shape do they take, and what are their consequences? 